\title{
THE REPUBLICAN PARTY AND THE LONG, HOT SUMMER OF 1967 IN THE UNITED STATES*
}

\author{
MARK McLAY \\ Glasgow Caledonian University/University of Glasgow
}

\begin{abstract}
A B S T R A C T. During the summer of 1967 , the United States experienced a series of race riots across the nation's cities as largely black neighbourhoods rebelled against the conditions in which they were living. The crisis reached its apogee in July when the worst riots since the American Civil War struck Detroit. In this atmosphere, legislators were faced with a stark choice of punishing rioters with stricter crime measures or alleviating living conditions with substantial federal spending. Despite being a minority in Congress, elected Republicans found themselves holding the balance of power in choosing whether the federal government would enforce law and order or pursue social justice for ghetto residents. While those Republicans who pursued 'order' have been given prominence in historiographical narratives, such politicians only represent one side of the Republican response. Indeed, moderate and progressive Republicans rallied to save Democratic President Lyndon B. Johnson's War on Poverty and a host of urban spending initiatives that had appeared politically doomed. These actions reveal that scholars have overestimated Republican conservatism during the I96os. Nonetheless, the rioting left a long-term legacy that enabled 'order' eventually to triumph over 'justice' in the following five decades.
\end{abstract}

On 15 September 1967 , the television network NBC aired an hour-long special report on the riots that had broken out across seventy-six American cities during the preceding summer months. ${ }^{1}$ The broadcast was filmed in Detroit, which two months previously had experienced the worst riots since angry New Yorkers had protested Abraham Lincoln's announcement of the

Io University Gardens, Glasgow, GI 2 8QQ markphd@hotmail.co.uk

* This article was written with support from the Lyndon B. Johnson Foundation, the Gerald R. Ford Foundation, the Rockefeller Foundation, and the Roosevelt Institute for American Studies. I am indebted to the expertise of the various archivists and librarians who aided my research in both the United States and the Netherlands. I am also grateful to my supervisor Prof. Robert Mason, and to the editors and reviewers of the Historical Journal who offered insightful commentary that has greatly improved this article from its original form.

1 Some scholars prefer to use the word 'rebellion' to describe such events. I have chosen to use the word 'riots' because that is how politicians and the media referred to them, and this is largely a work of political history. 
Union draft in 1863 . Occurring less than a week after another huge uprising in Newark, the five-day-long eruption in the Motor City left forty-three dead and resulted in the destruction of over 2,ooo buildings in largely black neighbourhoods. Yet, this special report was not aimed at a black audience. The tone of NBC's broadcast, anchored by journalist Frank McGee, was nearpleading with white viewers not to watch with their minds already closed by anger at the rioters. 'There's a great temptation to become shrill about what happened here in Detroit in July', McGee admitted, '[but] it's a temptation we wish to avoid.' Following dramatic footage of soldiers marching in the streets and buildings ablaze, McGee gravely intoned that the United States was in the midst of its worst crisis since the Civil War and the country was running out of time to find answers. ${ }^{2}$ Ultimately, the broadcast amounted to an appeal for action - for a policy approach that stressed social justice for black urban Americans, rather than a law and order clampdown across the United States that would satisfy the white 'backlash' sentiment apparent in the nation.

Throughout the 'long, hot summer' of 1967 , that choice - between 'order' and 'justice' - caused great debate among politicians in Washington, DC. On this crucial issue, the Democratic party - comfortably in the majority in both Houses of Congress and with liberal President Lyndon B. Johnson in the White House - was split between its Northern liberal wing and its Southern conservative wing, the latter still containing former segregationists who had little desire to funnel aid to African-Americans in the cities. As such, with the Democrats divided, elected Republicans found themselves holding the balance of power to decide whether the federal government would seek to relieve the ghetto conditions that had caused the riots or whether the rioters would feel the full force of American law enforcement. As the debate unfolded, it soon became apparent that the Republican party - portrayed by existing scholarship as merely the 'order' party - was similarly divided on this question. Thus, the immediate future of American social welfare policy hinged, not on a partisan struggle as one might expect, but on an intense intraparty debate.

Initially, it appeared that 'order' Republicans would triumph. Throughout the summer, Congress had been in a punitive mood, with the House passing a tough crime bill and cutting off funding for social programmes that aimed to alleviate the conditions in urban America. President Johnson, whose popularity plummeted over the summer of rioting, could only watch as the revived 'Conservative Coalition' of Southern Democrats and conservative Republicans even refused to appropriate money for a small programme aimed at exterminating rats in the nation's ghettos. Moreover, commentators suggested that the president's War on Poverty, launched amid such fanfare

\footnotetext{
2 'Summer of 1967', NBC Special Reports, National Broadcasting Company Network, 15 Sept.
} 1967 . 
only three years previously, was likely to be killed off by similar political forces. Yet, led by a moderate Republican reaction in both the Senate and the majority of governors' mansions, and a wave of unfavourable press coverage, the temper of Congress abruptly changed. Johnson achieved enactment of his rat extermination bill and a host of other urban funding that had previously been blocked, while the War on Poverty managed to evade the legislative axe. Ultimately, it was moderate and progressive Republican support that saved the president's social justice agenda in the late summer of 1967 .

Currently, however, existing scholarship conveys the impression that the Grand Old Party (GOP) pursued a purely punitive, 'law and order' response to the riots. Indeed, the prevailing historiographical narrative posits elected Republicans as mere purveyors of white backlash sentiment in their response to the riots. ' 'For the Republican party', Thomas and Mary Edsall contest, 'the riots provided the opportunity to change the direction of the national debate by initiating a full-scale assault on liberal social policies'. ${ }^{4}$ Meanwhile, Michael Flamm sees 'law and order' politics as a binding force that helped 'bridge divisions within the Republican Party'.5 Certainly, there were many in the GOP who did stoke the embers of white anger. Mostly found in the House of Representatives, these Republicans used the riots to further an agenda that sought to scale back Johnson's urban poverty programmes while simultaneously advancing stricter crime measures. Some elected Republicans even talked in openly racist language, although such politicians were a minority in the party. While these Republicans were undeniably prominent, they did not represent the consensus in the GOP throughout the summer of 1967 and beyond. Nevertheless, this one-dimensional portrait of the Republican response is consistent with much of the existing political history of the Johnson years.

Despite new studies emerging in recent years, the Johnson-era Republican party remains misunderstood and understudied. This situation has emerged as a result of two clear factors. First, much of the scholarship on the mid-tolate 1960 s focuses primarily on Johnson and the Democratic party. Such studies often ignore Republican politicians altogether or incorrectly portray the GOP's elected representatives as unthinking conservative allies of Southern Democrats in Congress during the $1960{ }^{6}$ Secondly, for those who

3 Malcolm McLaughlin, The long, hot summer of 1967 : urban rebellion in America (New York, NY, 2014); Thomas Byrnes Edsall with Mary D. Edsall, Chain reaction: the impact of race, rights, and taxes on American politics (New York, NY, 1992).

4 Edsall and Edsall, Chain reaction, p. $5^{1 .}$

5 Michael Flamm, Law and order: street crime, civil unrest, and the crisis of liberalism in the I96os (New York, NY, 2005), p. 11.

${ }^{6}$ For example, Allen J. Matusow, The unraveling of America: a history of liberalism in the I96os (New York, NY, 1984); Alonzo Hamby, Liberalism and its challengers: from FDR to Reagan (New York, NY, 1985); Gareth Davies, From opportunity to entitlement: the transformation and decline of Great Society liberalism (Lawrence, KS, 1996); Edsall and Edsall, Chain reaction. 
do look at the GOP, there has been an overriding desire to identify rising conservatism among Republicans and how this affected the party's internal dynamics. 7 This has resulted in a paucity of works that analyse the Republican party's impact on policy-making in this era and has also led to the omission of moderate and progressive Republicans from the historical record. ${ }^{8}$ This article seeks to redress this imbalance, portraying a politics that was more dynamic, more in flux, and sometimes even more bi-partisan, than the existing historiography would suggest. Ultimately, it will offer a history of the late 1960 s that is untethered to the narrative of right-wing ascendancy that was not especially evident in 1967 .

By 1967 , the Republican party was only just recovering from the electoral failure and intraparty division that Barry Goldwater's nomination had inflicted on the party in 1964. In such an environment, the ideological future of the party remained uncertain. For instance, the 1966 mid-term elections saw a Republican resurgence that pushed the House Republican caucus in a more conservative direction while simultaneously elevating moderate and progressive Republicans in the Senate. Indeed, many of the moderate and progressive Republicans whom historians now credit for their decisive support for the civil rights legislation of 1964 and $196_{5}$ enjoyed a resurgence of stature in the final two years of the Johnson presidency. Unsurprisingly, these Republican voices reacted to the violent eruptions in the nation's cities, not with cries for order, but with language and actions that emphasized social justice for those African-Americans who were rebelling against the conditions in which they lived. Even historians who acknowledge the existence of this group of Republicans assert incorrectly that such politicians were 'powerless' in the post-riots atmosphere of 1967.9

This article, therefore, analyses how, amidst the racial trauma of the long, hot summer of 1967 , the Republican party itself became divided between order and justice. It also explains how, for a fleeting moment, 'justice' Republicans successfully altered the course of American social welfare policy. As such, it challenges our currently skewed perception of the Republican party as it stood on the brink of an ascendant rise in American politics.

7 Mary Brennan, Turning right in the sixties: the conservative capture of the GOP (Chapel Hill, NC, 1995); Donald T. Critchlow, The conservative ascendancy: how the GOP right made political history (Cambridge, MA, 2007); Nicol Rae, The decline and fall of the Liberal Republicans: from 1952 to the present (New York, NY, 1989); Heather Cox Richardson, To make men free: a history of the Republican party (New York, NY, 2014); Lisa McGirr, Suburban warriors: the origins of the new American Right (Princeton, NJ, 2001); Matthew B. Lassiter, The silent majority: suburban politics in the Sunbelt South (Princeton, NJ, 2007).

${ }^{8}$ Geoffrey Kabaservice, Rule and ruin: the downfall of moderation and the destruction of the Republican party, from Eisenhower to the Tea Party (New York, NY, 2012), p. xvi.

9 Timothy Thurber, Republicans and race: the GOP's frayed relationship with African Americans, 1945-1974 (Lawrence, KS, 2013), p. 242. 
The Republican party, on the eve of the summer of 1967 , found itself in an intriguing moment. Less than three years had passed since the party's electoral nadir in 1964 when Barry Goldwater's landslide loss to LBJ in the presidential election had the knock-on effect of fostering Republican down-ticket disaster. Over the following two years, the Republican party sat largely powerless as the famous 89 th Congress $\left(1965^{-7}\right)$ enacted a host of Johnson's 'Great Society' legislation in policy areas such as health care, education, immigration, and urban poverty. Nevertheless, the party used this period in the political wilderness wisely. The Republican National Committee (RNC), previously a divisive body in the party, came under the control of arch-pragmatist, Ray Bliss, who refocused the party on the task of winning elections rather than the internal division that had characterized the GOP over the past twenty years. ${ }^{10}$ Moreover, most congressional Republicans began to present themselves as constructive opponents of Johnson's agenda, rather than further cementing the 'Party of No' moniker that had previously been levelled at the GOP since the emergence of the New Deal in the 1930s. ${ }^{11}$ This focus on unity and constructive opposition aided the Republican cause during the 1966 mid-term elections, in which the party made significant gains. ${ }^{12}$ In addition, it inspired increased confidence in the GOP that they would regain the White House in 1968. Spirits were so high that George Romney, governor of Michigan, giddily declared in May 1967 that 'It's fun to be a Republican.' 13

While the GOP was increasingly acting like a 'big tent' operation, the party did have four discernible factions - fundamentalists, stalwarts, moderates, and progressives. ${ }^{14}$ Fundamentalists were a rising force in the party, and had captured the party's presidential nomination when Goldwater ran in 1964, but contrary to the impression that historians such as Mary Brennan and Heather Cox Richardson have created, they did not succeed in capturing the party in the ${ }_{1960 s .}{ }^{15}$ Typically, fundamentalists emerged from the 'Sunbelt', an area running from Southern California to Virginia, and opposed all social welfare programmes while supporting a strengthening of federal crime laws. The largest group in the party were stalwarts, who tended to reside in the Republican heartlands of the Midwest and Mountain states. Unlike fundamentalists, they had

${ }^{10}$ Philip A. Klinkner, The losing parties: out-party national committees, 1956-1993 (New Haven, CT, 1994), pp. 78-83.

11 For example, in 1966, congressional Republicans proposed their own 'Opportunity Crusade' as a replacement for Johnson's War on Poverty.

${ }^{12}$ The 1966 mid-term elections resulted in Republican gains of forty-seven House seats, three Senate seats, and eight governor's mansions.

13 George W. Romney remarks at Michigan Federation of Republican Women, 5 May 1967, box 12, Robert Hardesty papers, Lyndon B. Johnson (LBJ) Library.

${ }^{14}$ Typology borrowed from A. James Reichley, Conservatives in an age of change: the Nixon and Ford administrations (Washington, DC, 1981), pp. 22-34.

${ }^{15}$ See Brennan, Turning right; Richardson, To make men free. 
voted for the civil rights acts, but, led by House Minority leader, Gerald R. Ford (R-MI), they also opposed most of Johnson's Great Society programmes and were not disposed to helping alleviate urban blight since most of these Republicans hailed from rural and small-town America. ${ }^{16}$ Moderates, most evident in the mid-Atlantic states, had largely voted in favour of Democratic social programmes such as Medicare and federal aid to education, while remaining sceptical of the War on Poverty and urban programmes that they perceived as either wasteful or corrupt, or both. Often ardent advocates of civil rights, they responded to the riots with empathy and sought to find uniquely Republican solutions, as exemplified by George Romney; a strong civil rights campaigner, who eschewed government welfare and sought to form voluntary alliances between business and government to support those in poverty. Finally, progressives, who were the smallest faction in the party but enjoyed disproportionate influence in the Senate, tended to offer similar solutions to liberal Democrats. Led by New Yorkers, such as Governor Nelson Rockefeller and Sen. Jacob Javits, these coastal Republicans championed the ideals of the War on Poverty and wanted to increase funding for the cities, sometimes beyond the levels that even the Johnson administration was proposing in 1967 . While these factions existed, infighting was largely avoided as the GOP became increasingly united by the prospect of victory in 1968 .

The emergence of the 'urban crisis' as the defining domestic issue between 1965 and 1968 offered an opportunity for Republicans. The long-simmering urban crisis - a term coined to reflect the combination of African-American urban uprisings, a perceived spike in violent crime, and the increased awareness of urban poverty - had exploded into the national consciousness in August 1965 when the Watts riots in a largely black neighbourhood of Los Angeles awoke the majority of Americans to the grievances of African-Americans residing in the urban North. ${ }^{17}$ This awakening, however, was not an entirely positive development for those African-Americans. Polls showed that Watts had a grave impact on the electorate, as support for both Democrats and further civil rights gains dropped immediately and dramatically among white Americans. ${ }^{18}$ This thus presented a political opportunity to a Republican party that was becoming a more cohesive and effective political force.

During the 1966 mid-terms, however, Republicans had no coherent strategy on how to maximize political benefit from the urban crisis. Given the option of stoking the white backlash and decrying government poverty programmes or providing a full-throated defence of racial progress, most Republicans fell somewhere in between. An example of such an approach was George H. W. Bush's

${ }^{16}$ Julian E. Zelizer, The fierce urgency of now: Lyndon Johnson, Congress and the battle for the Great Society (New York, NY, 2015 ), p. 13.

${ }_{17}$ Elizabeth Hinton challenges validity of rising crime statistics in Elizabeth Hinton, From the war on poverty to the war on crime (New York, NY, 2016).

18 Philip E. Converse, The dynamics of party support (Los Angeles, CA, 1976), p. 72. 
successful campaign to fill the newly created Houston-based House seat in Texas. Having lost his Senate race in 1964 to liberal Senator Ralph Yarborough while running on a Goldwaterite platform, Bush worked to repackage himself as a moderate in the intervening two years. Sean Cunningham describes how Bush, who had opposed the Civil Rights Act of 1964, emerged as a 'supporter of both antipoverty efforts and free enterprise, and as a leader relatively confident that government could solve the problems of urban decay, while also vaguely warning against too much intrusive government... Despite its inherent contradictions, the strategy worked.'19 All told, Republicans did not need to speak frequently about race or urban poverty; events were unfolding in such a way as to harm the Democratic party - now seen as the home of racial liberalism - by default. ${ }^{20}$ It would thus take the dramatic events of the summer of 1967 to push most Republicans off the fence.

At the same time as the Republicans were uniting, the Democrats were dividing. Johnson's Great Society vision was running aground on the rocks of the urban crisis and the divisions wrought by the Vietnam War. While Medicare and education funding had proved popular with the electorate, the War on Poverty - a high-profile part of the Great Society - was faltering and helping to expose Democratic party divisions. Liberal Democrats had become increasingly disillusioned by Johnson's efforts to provide a 'hand-up, not a handout' of poverty, and were advocating politically unrealistic entitlement payments to Americans in poverty. ${ }^{21}$ Meanwhile, Southern Democrats, who had long been suspicious of the War on Poverty, believing that it would disproportionately help black Americans, were abandoning the president's flagship programme.

Indeed, by 1967, despite having been launched amidst LBJ's tour of white Appalachia three years previously, the anti-poverty effort was widely perceived as targeting urban and black Americans. Political scientist Michael Brown argues that 'The War on Poverty, as it is well known, became clearly identified with the African American cause and served as one of the main routes to black political incorporation in the 1960 s... [It] was controversial precisely for these reasons.' ${ }^{22}$ As a result, Democrats were losing support among the Northern white working-class voters who believed the party was dolling out preferential treatment and welfare to the same 'work-shy' African-Americans who were rioting in the cities. One bumper sticker that appeared during 1966 was emblematic of this anti-welfare sentiment: 'JOIN THE GREAT SOCIETY GO ON WELFARE; I FIGHT POVERTY. I WORK.' ${ }^{23}$ Much to Republican

19 Sean P. Cunningham, 'John Tower, Texas, and the rise of the Republican South', in Robert Mason and Iwan Morgan, eds., Seeking a new majority: the Republican party and American politics, I96o-I980 (Nashville, TN, 2012), p. 73 .

20 Converse, Party support, p. 98.

21 See Davies, From opportunity to entitlement.

22 Michael K. Brown, Race, money, and the American welfare state (Ithaca, NY, 1999), p. 264.

23 Rick Perlstein, Nixonland: the rise of a president and the fracturing of America (New York, NY, 2008), p. 113 . 
delight, the Great Society coalition was looking decidedly shakier than its New Deal predecessor.

The urban crisis, therefore, was politically toxic for the Democratic party and the crisis reached its zenith during the summer of 1967 . In the calendar year alone, there were 164 disorders and riots in cities across 34 states. ${ }^{24}$ The Detroit riots, in particular, shook liberal Democrats who had previously seen the Motor City as an African-American success story. Johnson's former assistant secretary of labour, Daniel Patrick Moynihan, reflected in 1968 that 'Detroit had everything the Great Society could wish for in a municipality; a splendid mayor and a fine governor. A high-paying, and thanks to the fiscal policies of the national government, a booming industry, civilized by and associated with the hands-down leading liberal trade union of the world.' 25 The mayor, Jerome Cavanagh, had been an especially prominent supporter of the War on Poverty. ${ }^{26}$ What happened in Detroit and elsewhere thus heightened the focus on LBJ's Great Society programmes for urban and poor America. In short, as Malcolm McLaughlin notes, 'The long, hot summer...defined an arena in which political ideas were contested.' ${ }^{27}$

In the longer run, the summer of 1967 further shattered Great Society liberalism. Meanwhile, in the short term, the Democratic party's divisions presented an opportunity for Republicans - who remained a minority in both Houses of Congress - to exert outsized influence on how to tackle the urban crisis. Commentators, assessing the political landscape following GOP gains in the 1966 mid-term elections, believed that the result would be the end of the War on Poverty and the curtailing of further urban programmes that the Johnson administration might propose. ${ }^{28}$ Initially, such predictions appeared sound.

\section{I}

As the July riots took place, conservative voices in the GOP dominated the party's response. Sensing an opportunity to discredit Johnson and the War on Poverty, many Republicans sought to blame the Democrats for the summer's events. Moreover, they quickly endorsed attempts to scale back programmes that sought to benefit urban America, while simultaneously pursuing an approach to bring law and order to the ghettos. In sum, House Republicans saw in the riots an opportunity to discredit Great Society liberalism's focus on

\footnotetext{
24 Edsall and Edsall, Chain reaction, p. $5^{1 .}$

${ }^{25}$ Daniel Patrick Moynihan, 'Where liberals went wrong', in Melvin Laird, ed., Republican papers (Garden City, NY, 1968), p. 132.

${ }_{26}$ Correspondence, Jerome P. Cavanagh to Ford, 28 June $196_{5}$, folder 15 , box b28, congressional correspondence, Gerald R. Ford Library.

27 McLaughlin, Long, hot summer, p. 11.

${ }^{28}$ Lyn Shepard, 'U.S. legislative logjam seen', Christian Science Monitor, 12 Nov. 1966, p. 6; John H. Averill, 'Urban GOP worried by economy ax', Los Angeles Times, Nov. 1966; Edmond Lebreton, 'Reinforced Hill Republicans pick targets from president's programs', Washington Post, 12 Nov. 1966.
} 
social justice and to offer their own, alternative, 'order' prescription for the nation's social policy.

Minority Leader Ford led the Republican outcry against the War on Poverty. Slamming the raised expectations that Johnson and poverty war officials had created in the ghetto, and, as a first step to prevent rioting, Ford called immediately for 'A total re-vamping and re-direction of the Poverty War - where waste has been astronomical and administration ineffective.' ${ }^{29}$ Maryland Governor Spiro Agnew, for whom the riots appeared to have the effect of moving his political philosophy in a more conservative direction, backed the Minority leader in bemoaning the fact that federal programmes are 'overpublicized and underfunded'. $3^{\circ}$ California House Republican James Utt, blinkered to the numerous challenges facing ghetto dwellers, saw the money spent on the programmes as a waste. Utt blamed the ghetto conditions which led to the riots on a lack of initiative among the black population, claiming that it 'takes only effort to clean weeds and remove trash'. $3^{1}$

In the midst of the Detroit riot, the Republican Co-ordinating Committee (RCC) - a body comprised of eleven members of the Joint Senate-House leadership, five ex-Republican nominees for president, and five representatives from the Republican Governors Association (RGA) - endorsed the drive to blame Johnson. The RCC, which had been created following the 1964 debacle as vehicle for promoting unity in the GOP, released a statement on 24 July which accused the president and poverty workers of having stirred up the ghettos. Moreover, the statement attacked Johnson for not supporting a stronger crime bill to quell rioting. The St Louis Globe-Democrat described the RCC statement as 'the severest attack yet delivered by Republicans against the Johnson administration over Negro unrest'. ${ }^{2}$

It was in the House of Representatives where this line of attack manifested itself in policy. One such measure that showcased rising racial conservatism in the lower chamber was a rat extermination bill that the Conservative Coalition blocked on 20 July. The proposed legislation, which called for a modest appropriation of \$40 million to rid inner-city neighbourhoods of rats, attracted much opprobrium from House GOP members during debate and Republicans successfully voted 148 to 24 against consideration of the measure (Democrats supported it by 154 to 59 ). Congressional Quarterly noted that the bill's defeat was 'widely interpreted as being anti-President Johnson's “Great Society” and anti-poor people'.33

${ }^{29}$ Ford quoted from Joint Leadership Press Conference, 3 Aug. 1967, box 21, Research Unit (RU), governor's papers (GP), Ronald W. Reagan (RWR) Library.

$3^{\circ}$ Agnew quoted in Senate Republican Policy Committee memorandum, 3 Aug. 1967, Political activities of the Johnson White House, reel 19.

$3^{1}$ Utt quoted in Thurber, Republicans and race, p. 240.

$3^{2}$ Ray McHugh, 'Johnson fails to meet crisis, GOP charges', St Louis Globe-Democrat, 25 July 1967 .

33 'Antipoverty program survives assault', Congressional Quarterly Almanac (CQA) I967 (Washington, DC, 1968). 
The debate over the rat extermination bill often focused on issues of race, with opponents mocking the measure as a 'civil rats' bill.34 Iowa Republican Harold Gross derided the proposal of another federal programme, telling the House that the measure would lead to the establishment of a 'rat corps' and the appointment of a 'high commissioner of rats'.35 James Latta (R-OH) belittled the problem that the bill intended to solve, claiming that 'The matter of putting out a little bit of rat poison should not be requested of the Federal Government', and Virginia Republican Joel T. Broyhill made House Republican feelings clear, intoning in a Southern accent, 'I think the rat smart thing for us to do is vote down this rat bill rat now.' ${ }^{6} 6$ Thomas and Mary Edsall convincingly conclude that the distasteful debate over the rat extermination bill showed that 'The full force of white backlash had reached the House of Representatives.' 37

Johnson attempted to shame House Republicans into action, releasing a statement on the same day of the debate that portrayed the GOP as caring more about animals than about children: 'We are spending Federal funds to protect our livestock from rodents and predatory animals. The least we can do is give our children the same protection we give our livestock. ${ }^{38}$ In a further attempt to quell the rising storm of criticism aimed at the administration, Johnson employed the time-honoured tactic of appointing a commission to study the reasons behind the summer riots, with the National Advisory Commission on Civil Disorders (later known as the Kerner Commission) including three Republicans: Rep. William McCulloch (R-OH), Sen. Edward Brooke (R-MA), and New York Mayor John Lindsay. House Republicans, for the time being at least, were not placated, choosing to focus on their own solution to the riots.

The day before the rat extermination debate-cum-circus, House Republicans made clear that their priority was to re-establish order in the United States. Significantly, one of the very few pieces of noteworthy legislation bearing a Republican name which passed either chamber of Congress during the Johnson presidency was a crime bill on 20 July. This bill, if enacted, would have made it a crime to travel across state boundaries to incite a riot. Many perceived the bill, proposed by Florida Republican William Cramer, as a direct attack on militant 'black power' advocates Stokely Carmichael and H. Rap Brown. ${ }^{39}$ House Republicans approved the legislation by a margin of 179 to 4 as even progressive Republicans largely acquiesced in, or even contributed to, the new political mood of the country. Rising backlash sentiment was evident

\footnotetext{
34 'Congress 1967', CQA 1967.

35 Harold Gross, Congressional Record, 20 July 1967, p. 19548.

${ }^{6}$ James Latta, ibid., p. 19549; Joel Broyhill, ibid., p. 19548.

37 Edsall and Edsall, Chain reaction, p. 65.

$3^{8}$ LBJ quoted in Democratic National Committee press release, 'Reactionaries in Congress kill rat bill, President Johnson asks reconsideration', 21 July 1967, box 4o8, Frederick Panzer (FP) papers, LBJ Library.

39 Thurber, Republicans and race, p. 240.
} 
across the United States as national polls revealed that whites had a lower regard for black Americans than before the riots and, consequently, white opposition to any civil rights legislation had hardened. Furthermore, when asked by Gallup what their solution to the riots would be, whites most regularly favoured strong, repressive measures against the rioters. $4^{\circ}$ Accordingly, the House Republican alternative to Johnson's urban poverty initiatives clearly enjoyed majority support in the country.

This rising 'law and order' sentiment also provided a context that allowed fundamentalists, many of whom had been licking their wounds since Goldwater's heavy defeat, to regain more credibility in the GOP. In August, Ford went as far as describing the Arizonan as an 'oracle', noting that during the 1964 election the crime issue, which Goldwater had championed during his run, 'didn't have the ferment' it enjoyed in $1967 \cdot 4^{1}$ Meanwhile, newly elected California Governor Ronald Reagan's popularity continued to soar, not just in the Golden State, but throughout the nation. Reagan - a fundamentalist who referred to rioters as 'mad dogs' - had been ahead of the 'law and order' curve, essentially declaring his own war on crime in his January inaugural address. $4^{2}$ During a June speech in Indianapolis, entitled 'Little Minds and Timid Men Do Not Build Great Societies', Reagan had told the crowd that on the crime issue 'It is time to get angry.' 43 Reagan went on to excoriate liberals for social programmes that discouraged personal discipline and instead wrought 'Permissiveness from cradle to crime', which was embodied, according to the governor, by the 'right to adjust any grievance by the nearest means at hand, be it rock, club or firebomb'.44 A Harris poll in September revealed that 86 per cent of Americans knew who Reagan was, 82 per cent agreed that he was right in wanting to 'put a firm hand to race riots', and that, by an impressive four-to-one margin, respondents believed that he was doing a good job as governor. 45 Unsurprisingly, Reagan's name was mentioned with increasing frequency as a potential Republican candidate for the 1968 presidential race.

In this atmosphere, the House delivered its official response to the riots by passing the Republican-backed omnibus crime bill on 8 August and by continuing to refuse to fund urban poverty programmes. Washington Post journalist George Lardner Jr correctly noted that the 'crime issue ties in perfectly, as [Republicans] see it, with their calls for a cutback in the maze of often narrowly tailored federal aid programs'. ${ }^{6}$ As such, it was unsurprising that Ford and the

$4^{\text {o }}$ FP to LBJ, 15 Aug. 1967 , box 398 , FP papers, LBJ Library.

$4^{1}$ Ford quoted in George Lardner Jr, 'GOP blasts LBJ: rising crime stirs politics', Denver Post, 20 Aug. 1967.

$4^{2}$ Reagan, 'Inaugural address', 5 Jan. 1967, box 21 , RU, GP, RWR Library.

43 Reagan, 'Little minds and timid men do not build great societies', Indianapolis, IN, 13 June 1967 , box 127 , RU, GP, RWR Library.

44 Ibid.

45 Louis Harris, The Harris survey, 11 Sept. 1967, box 407, FP papers, LBJ Library.

$4^{6}$ Lardner Jr, 'GOP blasts LBJ', Denver Post, 20 Aug. 1967. 
House leadership continued to be obdurate in the face of increasing media pressure for the House to reverse-course and support Johnson's urban poverty programmes. In addition to blocking rat control funds, Ford remained defiant that the GOP would not provide votes to increase funds for Model Cities - a three-year-long, $\$ 1.2$ billion plan to co-ordinate a wide array of existing federal and local programmes aimed at attacking slum conditions - or to provide any appropriations at all for rent supplements, a programme which provided government assistance for poorer Americans to live in properties that they would normally not be able to afford. 47 Instead, House Republicans told reporters that, with crime legislation passed, the second solution to increased rioting was to provide more jobs.

At a Republican leadership press conference on 30 August, Ford reaffirmed the House Republican stance on rioting and in doing so summed up his caucus's order-focused response to Newark and Detroit: 'When a Rap Brown and a Stokely Carmichael are allowed to run loose to threaten lawabiding Americans with injury and death, it's time to slam the door on them - and slam it hard.' $4^{8}$ Ford's fellow Minority leader, Sen. Everett Dirksen (IL) offered similar sentiments, arguing that 'rioting and violent disorder have grown to a national crisis...no one is safe on the streets, in his home, or in his property...We are rapidly approaching a state of anarchy.' 49 McLaughlin notes correctly that, in his Dirksen's official capacity as Senate Minority leader, the Illinoisan was 'Speaking for the Republicans.'50 Yet, his message was far from reflective of the full range of Republican sentiment on the issue. Indeed, Dirksen was an outlier among his own Senate caucus. While it is well understood in the historiography that many Republicans reacted to the July riots with cries of 'order!', historians have neglected another voice that emerged from the GOP during the long, hot summer of 1967 .

\section{I I}

Senate Republicans chose a markedly different path when the riots took centre stage in July, and a short walk across Capitol Hill revealed a big difference in Republican thinking. Together with progressive governors, the majority of GOP senators offered support for Johnson's urban poverty initiatives at a crucial juncture for the Great Society. In a swipe at the House, a group of ten ideologically diverse Senate Republicans issued a statement on 27 July warning that 'Our cities and metropolitan areas, where most Americans live, face a grave crisis unless Congress lives up to its commitment made over the

47 Robert C. Albright, 'Dirksen, Ford claim LBJ losing crime war', Washington Post, 30 Aug. 1967 .

$4^{8}$ Gerald R. Ford quoted in ibid.

49 Dirksen quoted in McLaughlin, Long, hot summer, p. 7 .

$5^{\circ}$ Ibid. 
past two years.' 51 The statement, whose signatories included stalwarts such as Senators Frank Carlson and James Pearson of Kansas, as well as Iowa's Jack Miller, urged the House to fund Model Cities and rent supplements promptly at appropriate levels. $5^{2}$ The group also noted that the problems of the cities affected the suburbs and as such should be treated as metropolitan problems, thus including a key Republican voting base.53 Because of this approach, Senate Republicans - with the odd exception-rose above the mounting white backlash in diagnosing the reasons behind the riots. Kentucky's Thruston Morton summed up the sense of responsibility on display, declaring on 27 July: 'Blame is on us all.' 54

Approaching the riots in stark contrast to the House GOP, some Senate Republicans came very close to breaking the GOP's hallowed Eleventh Commandment - 'thou shall not speak ill of any Republican'.55 On 7 August, Hugh Scott released a statement in response to the farcical rat control debate, sarcastically describing the performance of the House as 'amazing'. Recounting the 'bad humor and poor jokes' during the debate, Scott scolded House members that 'Rats are hardly a topic for levity.' The Pennsylvanian, who would later tour rat-infested areas of Pittsburgh, announced that he had already introduced an identical rat control bill for consideration by the Senate. $5^{6}$ Maverick progressive Senator Thomas Kuchel (R-CA) also backed the administration's legislation and, somewhat surprisingly, admitted that he did not believe that Republicans always needed to offer alternatives to Democratic proposals. Speaking to the Los Angeles Times on 1 August, the Californian regretted that the Detroit riots put a 'considerable damper' on efforts to pass bills that benefited the black community. 57 Predictably, Jacob Javits, the foremost Republican progressive voice in the Senate, led the chorus of criticism against the House's behaviour, testifying that 'There seems to be little perceptiveness that while there may be some outside agitators, they are only riding the storm - not making it - and that the real agitators are slum landlords unmindful of their responsibilities, irresponsible public officials, bigots of all kinds - and rats.' $5^{8}$ Overall, Senate Republicans chose

$5^{1}$ Press release, 'Senator Scott and Republican colleagues urge funds for urban programs', 27 July 1967, box 39, Jacob K. Javits (JKJ) papers, Stonybrook University.

$5^{2}$ Ibid.

53 Ibid.

54 Morton quoted in Thurber, Republicans and race, p. 241.

55 The Eleventh Commandment was coined by California State Republican party chairman, Gaylord Parkinson, who was desperate to keep the Golden State's Republicans from splintering between hard-line conservatives who backed Reagan and moderates who backed his opponent.

$5^{6}$ Scott statement on rat control, 7 Aug. 1967, box 41, Hugh D. Scott (HDS) papers, University of Virginia; Scott, 'Senator Scott to tour rat infested areas of Pittsburgh', 16 Sept. 1967 , box 41 , HDS papers, University of Virginia.

57 Richard Bergholz, 'Kuchel backs president's racial programs: doubts GOP alternatives are needed', Los Angeles Times, 1 Aug. 1967.

$5^{8}$ Javits testimony to Housing Subcommittee, Senate Banking and Currency Committee, 25 July 1967, box 39, JKJ papers, Stonybrook University. 
to sympathize with ghetto residents, noting that only a small minority of residents ever participated in riots. There was an acceptance that 'law and order' legislation was going to pass, and even Javits admitted that he would begrudgingly vote for a crime bill, but the GOP caucus in the Senate showcased far more enthusiasm for programmes that focused on social justice. 59

Some Republican senators even offered legislation that was more progressive than that which Johnson administration was prepared to endorse. Thruston Morton, usually in line with stalwart thinking, called for a \$1 billion 'crash' programme to aid the cities in the immediate aftermath of the Detroit riots. ${ }^{60}$ Soon after, Javits advocated a 'Marshall Plan for Deprived Americans'. On 10 August, the empire state senator proposed that the federal government set aside one third of the surtax-currently being proposed to help fund the Vietnam War-to launch a ten-year anti-slum effort. Explaining the proposal, Javits noted that this would earmark the $\$_{5}$ o billion envisioned by the civil rights groups who, in late 1966, had proposed a 'Freedom Budget' for a variety of social and economic programmes, including a guaranteed minimum income for all Americans. ${ }^{61}$ To justify the significant outlay, Javits, who had first mooted such a programme in 1966, used the chaotic scenes throughout the summer, together with a rising resentment among Americans on the political left, in making the case that the country was sacrificing too much money in Vietnam. Sen. Charles Percy (R-IL), a moderate who had been elected in 1966 with the help of the white backlash vote that mobilized against his liberal opponent, also drew on the Guns and Butter theme. Percy told his fellow senators on 8 September: 'If we continue to spend $\$ 66$ million a day trying to save sixteen million people of South Vietnam while leaving twenty million poor in our own country unresolved then I think we have our priorities terribly confused.' ${ }^{2}$ Clearly, no one could accuse Senate Republicans of mimicking their House brethren in responding to the riots.

The Senate approach found favour with significant members of the RGA. Following a hastily called governors' meeting on 10 August, eleven Republican state executives, led by New York's Nelson Rockefeller, demanded a 'sweeping program to eradicate the root causes of rioting' ${ }^{6} 3$ In Rockefeller, who had already announced a $\$ 4.5$ million state rat control programme for New York, Johnson found a firm Republican ally. Indeed, ahead of the governors' meeting, the White House had provided Rockefeller with a list of currently stalled urban poverty legislation that he could persuade other GOP executives

\footnotetext{
59 Javits remarks during Senate news conference, 23 July 1967, box 39, JKJ papers, Stonybrook University.

60 William C. Selover and Lyn Shepard, 'Opposition to Great Society, Hardens', Christian Science Monitor, 5 Aug. 1967.

${ }^{6}$ James T. Patterson, The eve of destruction: how 1965 transformed America (New York, NY, 2012), pp. 224-5.

62 Percy quoted in Thurber, Republicans and race, p. 241.

63 Nathan Miller, 'GOP urged to support race bills', Baltimore Sun, 12 Aug. 1967.
} 
to endorse. ${ }^{6}$ Under Rockefeller's leadership, the governors released a sixtypoint plan which criticized the rigidity of existing federal urban programmes and also made clear that a firm hand was needed in response to rioting. Nevertheless, the overwhelming tone of the message was progressive. The eleven governors prioritized sympathy for ghetto residents, blaming the 'misery and frustration' which inner-city residents had to endure and urged Congress to supply funds that were currently being withheld from programmes such as Model Cities and rent supplements. ${ }^{6} 5$ Following the meeting, Ray Shafer, governor of Pennsylvania, impatient with House intransigence, went home and initiated Pennsylvania's own Model Cities programme. ${ }^{66}$

While Rockefeller's role was important, the most prominent Republican governor in the summer of 1967 was undoubtedly George Romney. When the Detroit riots struck in Romney's own backyard, he was a leading contender for the Republican nomination and was enjoying favourable poll ratings when matched against Johnson. ${ }^{6} 7$ Romney was acutely aware of the political challenge presented by urban America, having noted earlier in the year that 'It's an urban age, genuine urban renewal is of particular concern to the new generation because that's where most of them will spend their lives. ${ }^{\prime 68}$ Romney, despite being one of the eleven signatories to the governors' message, was no fan of the Great Society's urban initiatives, referring to the president's agenda as the 'Great Façade'. But he also had no time for the House Republican approach that focused solely on punishing rioters and criminals. ${ }^{69}$ The Michigander hoped to find a middle way that would provide him with a path to 1600 Pennsylvania Avenue. Romney's interest in attracting black voters to the GOP, his faith in volunteerism, and also his compassionate zeal to see the underdog succeed as he had done while in charge of American Motors (where he was in competition with larger companies such as Ford and General Motors) led the Michigander to set up the Detroit Action Centre in 1967 as a means of inner-city outreach. $7^{\circ}$ The Centre largely focused on providing advice to urban residents looking for jobs, chiming with Romney's consistent appeals throughout his career that self-help was a remedy to poverty.

In the wake of the riots, Romney redoubled his efforts to appeal to urban America, embarking on a tour of seventeen American cities over three weeks in September. After meeting with public officials, community leaders, and city

${ }_{4}$ Memo, Califano to Rockefeller, 9 Aug. 1967, Political activities of the Johnson White House, reel 19 .

65 Homer Bigart, '8 governors give antiriot program', New York Times, 11 Aug. 1967.

66 Republican Congressional Committee, 'Speech of the week', 11 Oct. 1967, box 34, series 1925 , HDS papers, University of Virginia.

${ }_{7}$ Kabaservice, Rule and ruin, p. 223.

68 Romney address at Lincoln Club Banquet, Louisville, KY, 11 Feb. 1967, folder 41o, box 18, series P-Whitman, $\mathrm{RG}_{4}$, Nelson A. Rockefeller papers, Rockefeller Archive Center.

69 Ibid.

$7^{\circ}$ Kabaservice, Rule and ruin, p. 214. 
residents throughout his tour, Romney concluded that while private initiatives were the most effective at tackling urban unrest, government had to do more to aid city residents. ${ }^{11}$ Employing dramatic rhetoric, Romney declared in late September: 'I am more convinced than ever before that unless we reverse course, [and] build a new America, the old America will be destroyed.'72 Unfortunately for those who agreed with the Michigan governor, by the time he made this declaration, Romney's star was already fading. While it is unclear if fundamentalist and stalwart Republicans could ever have rallied behind a Mormon moderate who had failed to endorse Goldwater in 1964, Romney's comments on 30 August that he had been 'brainwashed' by administration officials during a trip to Vietnam proved the death knell of his candidacy. Kabaservice argues that this represented a significant moment for the GOP's intraparty struggle, concluding that Romney's candidacy was the final chance for GOP moderates and progressives to leave a lasting imprint on the party.73 While Kabaservice's conclusion goes a step too far - Romney would be part of a Nixon administration that pursued progressive domestic legislation - it is certainly true that Romney's fall from grace meant that those advocating social justice in response to the problems of the ghetto had lost a significant spokesman for their cause.

Despite Romney's decline, Republicans who had advocated a progressive response to the summer's rioting saw legislative success emerge after tempers had cooled. While the long-term effects of riots would harm Great Society liberalism (and, indeed, Republican progressivism), in the short term, the 1967 summer riots actually had the effect of generating a sufficient sense of crisis to pass Johnson's urban poverty measures. Rat control, rent supplements, Model Cities, and, crucially, the Economic Opportunity Act - the omnibus poverty legislation that formed the core of the War on Poverty - all received funding to an extent that had seemed unlikely before the summer. The Senate approach of pursuing social justice gradually asserted itself over September and October and by acting as a check on the knee-jerk, populist white backlash embodied by the Conservative Coalition in the House, the upper chamber - Republicans included - performed one of the key functions for which the Senate had been created.

This process began on 20 September when over forty moderate House Republicans changed their votes on rat control, bowing to pressure from their Senate colleagues, the media, and the White House. Moreover, perhaps some of these Republicans were persuaded by the idea that government spending on urban programmes would restore a semblance of order to the nation's cities. The new bill was proposed in a bi-partisan spirit, with progressive House Republican Charles Mathias (R-MD) co-sponsoring the legislation.

$7^{1}$ Ibid., p. 217.

$7^{2}$ Romney quoted in ibid.

73 Kabaservice, Rule and ruin, p. 223. 
The next day, backed by a majority of GOP votes, the Senate passed a Model Cities appropriation of $\$ 537$ million - double what the House had passed in May, and the increased funding also included $\$ 40$ million for rent supplements. The appropriation was ultimately whittled down after the House, backed by the overwhelming majority of Republicans, rejected the original conference report which had agreed to the Senate's spending levels. Still, the \$312 million for Model Cities and \$10 million for rent supplements appropriations that passed in October represented a success for supporters of urban poverty initiatives. 74

After having its debate delayed to allow for a period of post-riot reflection by legislators, the Economic Opportunity Act was the final piece of legislation to profit from the riots. 75 Since the 1966 elections, the Johnson administration had feared that the renewed Conservative Coalition in the House would kill the legislation that was up for renewal in October. $7^{6}$ The Office of Economic Opportunity (OEO) - the co-ordinating hub of the War on Poverty-had been dogged by claims of wastefulness and corruption since its inception in 1964. Moreover, Republicans and Southern Democrats amplified claims during 1967 that the government anti-poverty agency was an expensive luxury that the nation could ill-afford during wartime.77 In a March message to Congress, Johnson had attempted to placate other prominent GOP criticisms by stressing a renewed focus on giving more power to the states to run OEO programmes and also further involvement from private enterprise. By 1967 , however, Great Society liberalism - of which the OEO remained the symbol was firmly perceived as an exercise in big government by the GOP and House Republicans, buoyed by Johnson's plummeting popularity, were not in the mood for compromise. Moreover, some observers saw the summer riots as throwing further doubt on the legislation to which Congress eventually returned in late September. $7^{8}$

Senate and House Republicans divided along similar lines as they had done in response to other urban poverty legislation. This is unsurprising as the Economic Opportunity Act was, by 1967 , just one part of the wider War on Poverty and, according to Congressional Quarterly, the legislation was now 'considered a plan for Northern cities and their large Negro populations'.79 Sen. Edward Brooke (R-MA), an African-American progressive and adopted Northerner whose Massachusetts electorate included Boston's substantial black population, delivered a passionate appeal to his fellow Republicans to embrace the War on Poverty and recognize the 'realities of the twentieth century'. Brooke, symbolically speaking in Detroit, called on House

74 'Congress 1967 ', CQA 1967.

75 'Antipoverty program survives assault, gets $\$ 1.8$ billion', CQA 1967 , p. 23.

$7^{6}$ Ibid.

77 Ibid.

$7^{8}$ Ibid.

79 Ibid. 
Republicans to seize their own Disraeli moment ${ }^{80}$ by fully meeting the challenge of urban poverty:

It is a sound tenet of the Republican Party that government should do for the people only what they cannot do for themselves. But what the people cannot do for themselves has, in many instances, increased. In the days when our country was young, a man could go West without money or education... These days are gone. Today's uneducated man lives in a slum.

To speak of free enterprise and equality of opportunity is to mock this young man and the multitudes who share his failure and frustration. Yet many Republicans share a fear that big, centralized government will undermine the freedom of the individual. ${ }^{81}$

As the only black senator, Brooke was afforded substantial media attention to articulate his views on the riots. Nonetheless, aside from Brooke and a handful of Democratic congressmen, the choice between 'order' and 'justice' acutely relevant to urban black Americans - would be voted on by an almost entirely white Congress.

Other Senate Republicans who, along with liberal Democrats, attempted to attach an Emergency Employment bill to the Economic Opportunity Act's renewal accepted Brooke's challenge. The bill - which bore resemblance to the Works Progress administration of the 1930s-would have authorized $\$ 2.5$ billion to help public and private agencies during 1968 and 1969 provide jobs for poor residents of slum ghettos and economically distressed rural areas. ${ }^{82}$ Despite the mention of rural areas, it was commonly accepted that the bill was in response to urban rioting; Hugh Scott justified his support of the measure by noting that the unemployment rate in the slums was three times the national average. Scott, who claimed the bill would create 5 oo,ooo jobs, also cited an appeal from Philadelphia's Republican district attorney Arlen Specter. Specter draped his call for the Emergency Employment bill with traditional Republican rhetoric: 'It is not possible for our urban centers to pull themselves up by their bootstraps without the assistance of the Federal Government.' ${ }^{3}$ Self-help rhetoric aside, the bill was a remarkably New Deal-like response to the riots and represents a Republican action which cuts against the existing narrative of Republicans during the summer of 1967 .

${ }^{80}$ With reference to nineteenth-century UK Conservative Prime Minister Benjamin Disraeli. Disraeli attempted to recast his party - often seen as the party of privilege - as the party of the rich and poor alike by embracing social and electoral reform to which the Conservative party had been traditionally opposed.

${ }^{81}$ Brooke speech to Republican party dinner, Detroit, MI, 9 Oct. 1967, box 57o, Edward W. Brooke papers, Library of Congress.

${ }^{82}$ Scott, 'Statement in support of the Emergency Employment Act', 26 Oct. 1967, box 41, HDS papers, University of Virginia.

${ }_{3}$ Arlen Specter quoted in ibid. 
Ultimately, the Emergency Employment section was removed, as the Johnson administration feared that its presence would sink the Economic Opportunity Act in the House. Both Javits and Scott tore into the president for failing to stand by a progressive response to the riots. ${ }^{8} 4$ Scott was especially scathing, skewering the president for ignoring the 'plight of the hard-core unemployed'. The Pennsylvania senator observed that 'The contrast between promise and performance has been one of the hallmarks of the Great Society, Mr. President, but it was never as evident as it is now. ${ }^{8}{ }_{5}$ Despite the failure of the Emergency Employment bill, Senate Republicans did help pass a two-year renewal of the Economic Opportunity Act which left the controversial OEO largely untouched and delivered an appropriation of $\$ 198$ million more than the administration had requested. With the battle seemingly already won by the administration, the final bill even attracted some support from GOP stalwarts with Republicans, including Dirksen and Karl Mundt (R-SD), voting 19 to 12 in favour of the Economic Opportunity Act's renewal on 5 October.

Predictably, the bill faced a stiffer challenge in the lower chamber. As in previous years, House Republicans once again attempted to propose their 'Opportunity Crusade' - essentially a watered-down version of the War on Poverty - as a substitute for the Economic Opportunity Act. The proposal, which would have scrapped the OEO, went nowhere, and Republicans who had also hoped to strip back most of the funding for the War on Poverty's central legislation were outmanoeuvred by liberal Democrats. Rep. Edith Green (D-OR) wrote a local-control feature into the bill that solidified support for the Economic Opportunity Act among big-city bosses and Southern Democrats. ${ }^{86}$ The latter, who could now tell their constituents that the OEO had less power to use federal money to push racial equality on the South, refrained from joining with Republicans at any stage to weaken the bill. Any hope of attracting Southern Democrats to the GOP side of the aisle ended when Republicans offended Southerners by labelling Green's proposal as a 'boll weevil' amendment. ${ }^{87}$

After much wrangling between the House and the Senate over funding levels, the Economic Opportunity Act's two-year renewal was eventually signed by LBJ on 23 December with an appropriation only slightly less than that which the administration had requested. Gareth Davies, reflecting on the political environment in which the renewal took place, concludes that 'The survival of the War on Poverty in these circumstances represented the administration's greatest legislative achievement in $1967 .{ }^{\prime 88}$ Taken together with the successful

${ }^{84}$ Javits remarks during Senate news conference, 3 Sept. 1967, box 39, JKJ papers, Stonybrook University.

${ }^{8}$ Scott, 'Statement in support of the Emergency Employment Act', 26 Sept. 1967.

${ }^{86}$ Big city mayors often fiercely resented that the Community Action aspect of the War on Poverty led to the creation of another powerbase beyond City Hall.

87 'Antipoverty program survives', CQA 1967.

88 Davies, From opportunity to entitlement, p. 196. 
passage of other legislation such as rat control, rent supplements, and Model Cities, it is clear that the riots had the short-term effect of spurring Congress - and especially the House - to acquiesce to funding urban poverty proposals that otherwise seemed doomed before the summer. With specific reference to the Republican party, the urban anti-poverty triumphs represented a short-term boost in status for Senate Republicans who had led the way in calling for such legislation, but the overwhelming trend of white backlash sentiment amongst the public, which rejected social welfare programmes for inner-city residents, suggested that those favouring social justice for the ghetto were not likely to remain in the ascendancy for long.

\section{V}

Notwithstanding the divided response that Republicans offered to the riots, the GOP proved itself capable of being a 'big tent' party as the differing approaches did not lead to a breakdown in party unity. In the midst of the summer crisis, thirty-five House Republicans and ten Senate Republicans of varying political ideologies had released a statement entitled 'Preventative medicine in the cities' which perfectly balanced appeals to both order and justice: 'All responsible men know that stern measures must be taken to assure that law and order will prevail. But we should not make the mistake of weakening or abandoning the Nation's commitment to equal opportunity and equal justice for all.' 89

Much like the Democrats, who had spoken with two distinct voices on the issue of racial segregation since the 1930s, Republicans were applying a similar response to the urban crisis. Senate Republicans could argue that they had salvaged urban poverty measures while not ignoring - at least rhetorically - the need to restore order to the cities. House Republicans, on the other hand, could justifiably claim that they had put a check on the big spending of Great Society liberalism and firmly advocated a restoration of order. While journalists often tried to tempt Republicans into denouncing these contrasting points of view, GOP politicians, mindful of the Eleventh Commandment, were careful to avoid any divisive comments. $9^{\circ}$ This was not to be a return to the internal dysfunction of the early 1960 , which had led journalist Theodore White to classify the Republicans as 'fratricidal'. $9^{1}$

Undoubtedly, such unity was helped by the fact that the riots further eroded the credibility of Johnson and the Democratic party to such an extent that Republican victory in 1968 seemed increasingly likely. An RNC meeting held in September - at which point the president's approval rating had fallen to

\footnotetext{
89 Various, 'Preventative medicine in the cities', 3 Aug. 1967, box 41, HDS papers, University of Virginia.

$9^{\circ}$ John Herbers, 'House liberals waver', New York Times, $3^{\circ}$ Oct. 1967.

$9^{1}$ White quoted in Kabaservice, Rule and ruin, p. xvii.
} 
37 per cent - showcased the increased confidence in Republican ranks. $9^{2}$ Lee Nunn, director of the National Republican Senatorial Campaign Committee, observed that 'The Press and commentators across the Nation are, as usual, having a field day as to what political philosophy we Republicans should embrace to ensure victory next year.' Nunn, who reminded the gathering that the membership comprised ideologically diverse figures ranging from the progressive Jacob Javits to the arch-conservative and former segregationist Sen. Strom Thurmond (R-SC), confidently asserted that 'Fortunately, we do not have a philosophical problem with our committee...We are all going to be running against the Johnson administration-unity of purpose should present no difficulty.'93 Nunn was likely drawing strength from the GOP's pollster Thomas Benham, who told the meeting that such was the public anxiety over the summer riots and the prolonged Vietnam War that the GOP could win in 1968 even if LBJ somehow managed soon to bring the conflict in Southeast Asia to a successful conclusion.94 Sen. Margaret Chase Smith (R-ME), who possessed a voting record that was largely progressive, believed that people were yearning for a return to Eisenhower's America when people 'could walk the streets of our cities and towns without such great fear of being attacked'. 95

Ultimately, the twin responses of 'order' and 'justice' would resurface during the 1968 presidential primary and beyond. Ronald Reagan quickly emerged as the candidate of order, while Nelson Rockefeller took on the mantle of social justice candidate, but it was Richard Nixon - who combined an appeal to both wings of the party - who was the eventual nominee. Indeed, it is instructive that Nixon - a bellwether for the party's ideological middle ground due to his pragmatic approach to domestic policy - called for increased crime control and a scaling-back of the War on Poverty, but also for 'black capitalism' to restore urban areas. Indeed, throughout his journey to the White House in 1968, Nixon would loudly embrace 'order' while also issuing a quieter appeal for 'justice', and, in doing so, he would-to misappropriate a former Republican slogan - offer the electorate both a choice and an echo. Moreover, once ensconced in 1600 Pennsylvania Avenue, Nixon would begin the War on Drugs and attempt to close the OEO, but also propose the most radical approach to poverty in decades, in the form of the Family Assistance Plan. Nixon would also appoint George Romney as his secretary for housing and urban development, while Hugh Scott would emerge as the Senate Minority leader in 1969 and prove resistant to Nixon's overt offerings to Southern fundamentalists in the GOP. As such, there was no immediate end to the intraparty

$9^{2}$ Presidential Job Approval, 'Lyndon B. Johnson', Gallup data compiled by Gerhard Peters, The American presidency project, www.presidency.ucsb.edu/data/popularity.php.

${ }^{93}$ Lee Nunn remarks during RNC meeting, 8 Sept. 1967, Papers of the Republican party, reel 6.

94 James G. Wieghart, “War, riots “could help unseat LBJ”, Milwaukee Sentinel, 9 Sept. 1967.

95 Margaret Chase Smith remarks during RNC meeting, 8 Sept. 1967, Papers of the Republican party, reel 6 . 
ideological disparity between order and justice that had been revealed in the summer of 1967 . Arguably, it would not be until the landmark 1980 election, which witnessed the defeat of many progressive Republicans and the election of Ronald Reagan, that the social justice impulse in the party was truly overwhelmed.

Ultimately, the Republican party's dual response during the summer of 1967 undermines existing historiographical narratives that characterize the late 1960 GOP as a party captured by 'movement conservatives', hell-bent on rolling back Great Society liberalism..$^{6}$ If anything, the party's conflicting response to the riots hinted at the challenges the GOP would face when Republicans were returned to power. Indeed, in analysing the party's response in 1967 , it becomes less surprising that Republicans over the following four decades were comfortable reaping political benefit from denouncing 'big government', but were less assertive when it actually came to dismantling Great Society programmes passed during the Johnson era. Ironically, the one exception to this was the War on Poverty, which was symbolically ended by the Nixon administration's aggressive attempts to shutter the OEO. Nevertheless, in 1967 , the GOP was presented with a chance to kill the War on Poverty - the Great Society initiative they liked the least-and they failed to do so in a political climate that could hardly have been more pliable to ending a programme that was perceived as helping the same urban black residents on whom the majority of Americans were turning their backs. This confirms that there remained significant ideological differences among the party's elected members and that scholarly characterizations of Republicans as reacting in a singular coherent way to any important issue during the late 1960 are woefully simplistic.

Further, the Republican party's behaviour in response to the riots is instructive when considering what exactly it meant to be a 'united' political party in the era prior to the extreme polarization of recent decades. Stark differences existed between GOP representatives, particularly between House and Senate members, yet the party managed to keep the veil of unity intact. This was achieved through various mechanisms that encouraged unity, such as the RCC, a pragmatic RNC chairman, and a respect among its members for the party's newly minted Eleventh Commandment. Such stabilizing factors - a result of lessons learned from the divisive Goldwater campaign - helped ensure that, unlike in 1964, any lingering grievances were largely kept away from the public eye. Moreover, unity was further engendered by the sense among its members that the GOP, after thirty years spent largely in the political wilderness, was on the cusp of victory over a divided Democratic party. Pragmatic

$9^{6}$ See Richardson, To make men free. 
considerations therefore trumped ideological divisions, ensuring that, for the most part, both 'order' and 'justice' Republicans would lustily cheer Richard Nixon to victory in 1968.

Beyond the implications for the Republican party - that the social justice approach was eventually embraced in the long, hot summer's wake - larger questions are raised. Did the riots inspire politicians to pay more attention to those who were rebelling? And, as a result, were riots a successful tool for attracting government funding for the nation's cities? In the short term, the answer to both is 'yes'. It seems likely that without the long, hot summer's intense and shocking events, Congress was poised to dismantle urban programmes that were beneficial to the communities from which the rioters came. The War on Poverty, especially, seemed destined for the legislative axe in 1967. Some legislators who eventually acquiesced to refunding social welfare programmes were likely doing so because they feared further riots or because their consciences were pricked by events in Newark and Detroit.

Nonetheless, in the long term, the summer of 1967's events were devastating for those advocating social justice for African-Americans living in ghetto conditions. Since the 196os, urban programmes, stigmatized as minority-focused, have failed to achieve broad political support in the United States. For instance, despite its stay of execution, the War on Poverty's increased association with urban black Americans ensured that it was unceremoniously abandoned in 1981. In its stead, the United States embarked on two other 'wars' - the 'War on Crime' and the 'War on Drugs' - both of which would disproportionately impact African-Americans in the nation's cities and lead to mass incarceration on an unprecedented scale. Indeed, in 2017 , the US - which contains $4 \cdot 4$ per cent of the world's population - had a prison population that accounted for 23 per cent of the world's incarcerated people.97 As of July 2017, AfricanAmericans - who constitute 13.2 per cent of the American populationrepresent 37.8 per cent of the country's prisoners..$^{8}$ Fifty years on, it is clear that the United States eventually succumbed to the white backlash impulse that House Republicans had epitomized in July 1967 and, in the final analysis, 'order' won out over 'justice'.

97 Peter Wagner and Bernadette Rabuy, 'Mass incarceration: the whole pie 2017', Prison Policy Initiative, 14 Mar. 2017, www.prisonpolicy.org/reports/pie201 7.html.

$9^{8}$ 'Inmate race', Federal Bureau of Prisons, 29July 2017 , www.bop.gov/about/statistics/statistics_inmate_race.jsp. 